J. Dairy Sci. 99:2641-2653

http://dx.doi.org/10.3168/jds.2015-9693

(C) 2016, THE AUTHORS. Published by FASS and Elsevier Inc. on behalf

of the American Dairy Science Association ${ }^{\circledR}$. This is an open access article under

the CC BY-NC-ND license (http://creativecommons.org/licenses/by-nc-nd/3.0/)

\title{
Identification and molecular phylogeny of coagulase-negative staphylococci isolates from Minas Frescal cheese in southeastern Brazil: Superantigenic toxin production and antibiotic resistance
}

\author{
Raquel Soares Casaes Nunes, ${ }^{*}$ Camilla Pires de Souza, $†$ Karen Signori Pereira, $†$ Eduardo Mere Del Aguila, ${ }^{*}$ \\ and Vânia Margaret Flosi Paschoalin*1 \\ *Instituto de Química, and \\ †Escola de Química, Universidade Federal do Rio de Janeiro, Av. Athos da Silveira Ramos 149, Cidade Universitária, 21949-909, Rio de Janeiro, \\ RJ, Brazil
}

\begin{abstract}
Minas Frescal is a typical Brazilian fresh cheese and one of the most popular dairy products in the country. This white soft, semiskimmed, nonripened cheese with high moisture content is obtained by enzymatic coagulation of cow milk using calf rennet or coagulants, usually in industrial dairy plants, but is also manufactured in small farms. Contamination of Minas Frescal by several staphylococci has been frequently reported. Coagulase-negative staphylococci (CNS) strains are maybe the most harmful, as they are able to produce heat-stable enterotoxins with super antigenic activities in food matrices, especially in dairy products such as soft cheeses. The aim of the present study was to investigate the presence of CNS strains in Minas Frescal marketed in southeastern Brazil concerning the risk of staphylococci food poisoning by the consumption of improperly manufactured cheese and the possibility of these food matrices being a reservoir of staphylococcal resistance to antimicrobials. Ten distinct CNS strains were found in 6 cheeses from distinct brands. The most frequent species were Staphylococcus saprophyticus (40\%), Staphylococcus xylosus (30\%), Staphylococcus sciuri (20\%), and Staphylococcus piscifermentans (10\%). Three strains were identified to the Staphylococcus genera. Three major species groups composed of 3 refined clusters were grouped by phylogenetic analyses with similarities over to $90 \%$. All CNS strains carried multiple enterotoxin genes, with high incidence of sea and seb (90 and 70\%, respectively), followed by sec/ see, seh/sei, and sed with intermediate incidence (60, 50 , and $40 \%$, respectively), and, finally, seg/selk/selq/ selr and selu with the lowest incidence (20 and 10\%,
\end{abstract}

Received April 9, 2015.

Accepted November 17, 2015.

${ }^{1}$ Corresponding author: paschv@iq.ufrj.br respectively). Real-time reverse transcription PCR and ELISA assays confirmed the enteroxigenic character of the CNS strains, which expressed and produced the enterotoxins in vitro. The CNS strains showed multiresistance to antimicrobial agents such as $\beta$-lactams, vancomycin, and linezolid, which have therapeutic importance in both human and veterinarian medicines. The risk of staphylococci food poisoning by the consumption of improperly manufactured Minas Frescal was emphasized, in addition to the possibility of these food matrices being a reservoir for antibiotic resistance. More effective control measures concerning the presence and typing of staphylococci in raw milk and dairy derivatives should be included to prevent the spread of pathogenic strains.

Key words: classical and newly described enterotoxins, enterotoxin-encoding gene transcription and expression, multiresistance to antimicrobials, real-time reverse transcription PCR

\section{INTRODUCTION}

Bacteria belonging to the Staphylococcus genus can cause a multitude of diseases in humans. As essentially opportunistic microorganisms, these pathogens can cause severe infections, especially among immunocompromised people, and are often difficult to treat because of the relatively high prevalence of multiresistant strains (Zell, et al., 2008). Healthy people can be affected by staphylococci if they are transmitted by food products, as these microorganisms have the ability to secrete several types of toxins, many of which are responsible for food poisoning.

According to the Brazilian Ministry of Health (Ministério da Saúde), staphylococcal poisoning is the second most common food-borne disease in Brazil, only behind outbreaks involving Salmonella spp. (ICMSF, 2006). Staphylococcal food poisoning is a gastrointestinal ill- 
ness caused by the ingestion of contaminated food containing enterotoxins produced by bacteria belonging to this genus. These enterotoxins exhibit super antigenic activities and are heat stable proteins that may not be destroyed under inadequate cooking.

Among the pathogens belonging to Staphylococcus genus, those organisms classified as coagulase positive, such as Staphylococcus aureus, are considered potential food enterotoxin-producing species (ICMSF, 1983). However, the possibility of CNS being involved in food poisoning has been also raised (Veras et al., 2008) after it was shown that these microorganisms can also carry enterotoxin-encoding genes ( $s e$ genes) in their genomes (Rall et al., 2010); these have been found in processed meat (Pereira et al., 2009) and in dairy products, especially cheeses (Senger and Bizani, 2011).

The enterotoxin (SE) genes are encoded in mobile genetic elements, such as plasmids, prophages, and Staphylococcus pathogenic islands. Those mobile genetic elements are responsible for the horizontal transfer of virulence or antibiotic resistance genes between $S$. aureus strains (Ubeda et al., 2005; Maiques et al., 2006), and it has also been suggested that the exchange of mobile DNA elements between microorganisms might occur during food processing (Virdis et al., 2010).

Staphylococcal toxins are designated as SE with demonstrated emetic activity, whereas staphylococcal-like toxins are named SE-like (SEl) and showed no emetic activity in primate models or have not yet been tested (Lina et al., 2004). To date, $21 \mathrm{SE}$ and SEl toxins have been reported. In addition to the five well-characterized, classical staphylococcal enterotoxins - SEA, SEB, SEC, SED, and SEE - 6 new types of SE (SEG, SEH, SEI, SER, SES, and SET) and 10 new types of SEl (SElJ, SE $/ K, \mathrm{SE} l \mathrm{~L}, \mathrm{SE} l \mathrm{M}, \mathrm{SE} / \mathrm{N}, \mathrm{SE} l \mathrm{O}, \mathrm{SE} l \mathrm{P}, \mathrm{SE} l \mathrm{Q}, \mathrm{SE} / \mathrm{U}$, and SEIV) have been introduced (Argudin et al., 2010).

The Minas Frescal (fresh) is a typical Brazilian cheese produced since the 18th century (Campos, 2001); even now it is one of the most popular cheeses consumed in southeastern Brazil. It is a white soft cheese, produced from cow milk, and its major characteristic is a pleasant, slightly acid taste and rich flavor (Kamiyama and Otenio, 2013). A method to avoid Minas Frescal adulteration via replacement of milk by whey has been developed (Magenis et al., 2014).

According to the current Brazilian legislation (Brasil, 1997), the Minas Frescal cheese is a fresh cheese obtained by enzymatic coagulation of cow milk using calf rennet or coagulants. Specific lactic acid bacteria can complement the enzymatic milk coagulation. Minas Frescal cheese is a semiskimmed product with low saturated fat content. It is considered a lean protein source with high digestibility, and it is the dairy-derived prod- uct most often consumed in energy-restricted diets for weight loss (Moraes et al., 2009). In addition, Minas Frescal can be considered a functional food when lactic acid bacteria are used in manufacturing because of its health benefits, including reducing the risk of human diseases (Stringheta et al., 2007; Almeida et al., 2008). The production of Minas Frescal cheese has increased from 42,700 tons in 2000 to 63,555 t in 2011, placing it third among cheeses produced in the country, behind only Mozzarella and Prato cheese, a Brazilian semihard cow variety of cheese (Cichoscki et al., 2002). The manufacturing of Minas Frescal cheese may occur in dairy industrial plants, but it is also commonly manufactured by small producers with inadequate manufacturing practices and can undergo excessive manipulation (Bulhões and Rossi Junior, 2002).

Soft cheeses do not undergo any treatment while ripening to ensure their safety before consumption. Staphylococci can contaminate soft cheeses by improper handling during processing, inadequate storage conditions, use of contaminated milk, or even due to the physico-chemical features of the cheese matrix, such as high $\mathrm{pH}$, high water activity, and low salt concentrations, which are favorable to the growth of these microorganisms (Viana et al., 2009). Outbreaks caused by enterotoxigenic Staphylococcus strains would hardly be associated with the contamination of Minas Frescal soft cheese, as it is considered a healthy and harmless food for the Brazilian population (Silva and Souza, 2006).

The main species of CNS prevailing in dairy products are Staphylococcus sciuri, Staphylococcus xylosus, Staphylococcus epidermidis, Staphylococcus haemolyticus, and Staphylococcus lentus (Soares et al., 2011), as well as several strains isolated from different sources shown to be resistant to antibiotics of therapeutic relevance (Kästner et al., 2006; Martin et al., 2003), mainly penicillin and synthetic $\beta$-lactams represented by oxacillin, vancomycin, and linezolid (Virdis et al., 2010). Many of these oxacillin-resistant microorganisms also present resistance to other antimicrobials, thus limiting the use of glycopeptides such as vancomycin and linezolid (Resch et al., 2008).

For a long time, $S$. aureus, a coagulase-positive staphylococci, has always been thought to be the only pathogenic species among Staphylococcus spp., whereas CNS are, even today, classified as contaminant agents. In Brazil, current legislation (Brasil, 2001) establishes $10^{3} \mathrm{cfu} / \mathrm{g}$ as the upper tolerance limit count for coagulase-positive staphylococci in soft cheese matrices, whereas CNS are neglected as contaminant microorganisms in food.

Staphylococcal enterotoxin producers are a public health problem, as food processing does not inactivate 
these toxins. According to the Centers for Disease Control and Prevention (http://www.cdc.gov/nczved/ divisions/dfbmd/diseases/staphylococcal/), staphylococcal food poisoning can cause a brief illness of 1 to $3 \mathrm{~d}$, but highly susceptible patients, such as the young and the elderly, are more likely to have severe illness requiring intravenous therapy and hospital care.

The aim of the present study was to evaluate the CNS contamination of Minas Frescal cheeses marketed in Rio de Janeiro, Brazil. The identification of the main CNS strains was performed by DNA sequencing and their phylogenic relationships were established. The presence of multiple genes encoding the classical and newly described enterotoxins in CNS genomes was investigated. The risk of food poisoning was assessed by evaluating the ability of the CNS strains in transcribing and expressing the classical and newly described enterotoxins in vitro by using real-time reverse transcription PCR and ELISA assays. The resistance of the isolated strains to antimicrobial agents of therapeutic importance in staphylococcal infections was also evaluated.

\section{MATERIALS AND METHODS}

\section{Isolation of Bacterial Strains and Growth Conditions}

A bulk sample consisting of 6 Minas Frescal cheeses from distinct brands inspected by municipal, state, or federal food inspection services and collected in the municipality of Rio de Janeiro were stored in low-density polyethylene bags. Samples showed acidic $\mathrm{pH}$ of 5.6 to $5.8,3.0$ to $4.0 \mathrm{mg}$ of sodium, and water activity $\left(\mathrm{A}_{\mathrm{w}}\right)$ of 0.93 to 0.96 . Twenty-five grams of cheese was added to $225 \mathrm{~mL}$ of $0.1 \%$ peptone water. The suspensions were transferred to homogenizer bags (Interscience, Saint Nom, France) and coupled to a Stomacher 400 circulator (Seward, Worthing West Sussex, UK) at $260 \mathrm{rpm}$ for $1 \mathrm{~min}$. The suspensions were serial diluted from $10^{-6}$ to $10^{-1}$ and $100 \mu \mathrm{L}$ of each dilution was inoculated onto $20 \mathrm{~mL}$ of Baird-Parker agar containing egg yolk tellurite emulsion (BPAp RPF, bioMerieux, Marcy $\mathrm{l}^{\prime}$ Etoile, France) and incubated at $37^{\circ} \mathrm{C}$ for $24 \mathrm{~h}$. Conventional microbiology procedure were performed following instructions to the Bergey Manual of Systematic Bacteriology (Garrity et al., 2005), where 80 colonies presumptive of CNS (3-10 colonies of each sample) were tested by Gram staining and catalase, coagulase, and thermostable DNAase activities. The 60 presumptive CNS strains were stored at $-80^{\circ} \mathrm{C}$ in tryptone soy agar (BD BBL, Franklin Lakes, NJ) plus $45 \%$ vol/vol glycerol. Cultures were grown in brain heart infusion (BD BBL) medium at $37^{\circ} \mathrm{C}$ for $24 \mathrm{~h}$.

\section{DNA Preparation}

The isolated strains were cultured overnight aerobically in $10 \mathrm{~mL}$ of brain heart infusion broth (BD BBL) at $37^{\circ} \mathrm{C}$ for $24 \mathrm{~h}$. The suggestive CNS colonies were grown up to optical density at $600 \mathrm{~nm}\left(\mathrm{OD}_{600}\right)=0.5$, which corresponds approximately to a concentration of $10^{6} \mathrm{cfu} / \mathrm{mL}$, were harvested by centrifugation at 5,700 $\times g$ for $1 \mathrm{~min}$ at room temperature. The cell pellet was used for DNA extraction using the DNeasy blood and tissue kit (Qiagen, Dusseldorf, Germany), following the manufacturer's instructions. Genomic DNA was quantified using the Qubit fluorimeter and Qubit assay kits (Invitrogen, Grand Island, NY).

\section{$16 S$ rDNA Sequencing}

Amplification of the V5 region of $16 \mathrm{~S}$ rDNA was performed using $50 \mathrm{ng}$ of DNA templates from the 60 strains isolated from Minas Frescal cheeses. A PCR was performed under the following conditions: $95^{\circ} \mathrm{C}$ for 10 min, followed by 30 cycles at $95^{\circ} \mathrm{C}$ for $30 \mathrm{~s}, 60^{\circ} \mathrm{C}$ for 30 $\mathrm{s}$ and $72^{\circ} \mathrm{C}$ for $45 \mathrm{~s}$, and a final extension at $72^{\circ} \mathrm{C}$ for 10 min. The PCR products were purified using the PCR DNA Purification kit (Applied Biosystems, Thermo Fisher Scientific, Waltham, MA) and sequenced using $20 \mathrm{ng}$ of purified DNA and $13 \mu \mathrm{L}$ of primer set of forward and reverse 16S rDNA (Table 1) in a final volume of $20 \mu \mathrm{L}$. After the amplification, products were purified according to the protocol of the BigDye Terminator Purification X kit (Applied Biosystems) and sequenced in a 3130 sequencer Genetic Analyzer (Applied Biosystems). Staphylococcus species identification was performed by comparing the partial sequences of $16 \mathrm{~S}$ rDNA to the sequences available at GenBank database (http://www.ncbi.nlm.nih.gov/Genbank/index.html). The nucleotide sequences were then submitted to GenBank, which provided new accession number to each isolated strains of Staphylococcus species available in the GenBank database. Multiple sequence alignments were performed using ClustalW (Kyoto University, Bioinformatics Center; http://www.genome.jp/tools/ clustalw/).

\section{Phylogenetic Analyses}

Phylogenetic relationships among the CNS strains were performed by the alignment of sequences using the Clustal X 2.0 software (Larkin et al., 2007). The phylogenetic trees were constructed using the software Mega 6.0 and UPGMA methods (Sneath and Sokal, 1973). 


\section{PCR Tests}

Primer Sequences, Target Genes, and Species. Primer sets flanking the sea, seb, sec, sed, see, selg, selh, seli, selk, selm, seln, selo, selq, selr, and selu sequences are listed in Table 1.

Uniplex-Duplex and Multiplex-PCR Tests. Uniplex-PCR tests were performed for amplifying the test sequence and duplex-PCR was used with the sea, seb primers and sec, sed primers. The PCR mixtures contained $25 \mu \mathrm{L}$ of $20 \mathrm{mM} \mathrm{MgCl} 2,10 \times$ PCR buffer (Invitrogen), $100 \mathrm{~m} M$ dNTP mix (Fermentas Thermo Scientific, Vilnius, Lithuania), $0.2 \mathrm{~m} M$ of each primer (Table 1), $0.5 \mathrm{U}$ of Taq DNA polymerase (Invitrogen), and $100 \mathrm{ng}$ of DNA templates. The DNA amplification by uniplex- and duplex-PCR assays were performed under the following conditions: $94^{\circ} \mathrm{C}$ for 5 min followed by 35 cycles of $94^{\circ} \mathrm{C}$ for $2 \mathrm{~min}, 53^{\circ} \mathrm{C}$ for $2 \mathrm{~min}$, and $72^{\circ} \mathrm{C}$ for 1 min for extension, ending with a final extension at $72^{\circ} \mathrm{C}$ for $7 \mathrm{~min}$, according to the conditions described by Mehrotra et al. (2000) with modifications in the annealing temperature using a thermal cycler (MyCycler, Bio Rad, Hercules, CA). The amplified fragments were visualized on 1.0\% agarose gels (SigmaAldrich, St. Louis, MO) stained with GelRed (dilution 1:1000; BioAmerica, Tel Aviv, Israel) and documented on a transilluminator (MiniLumi Imaging Bio-Systems, BioAmerica).

Multiplex-PCR Tests. Multiplex-PCR assays were performed by simultaneous amplification of the see, selg, selh, seli, selj, selm, seln, selo, selk, selq, selr, and selu sequences using the primer sets listed in Table 1. Each reaction contained $50 \mu \mathrm{L}$ of a mix containing 0.5 $\mathrm{U} / \mu \mathrm{L}$ of Taq DNA polymerase, $10 \times$ PCR buffer, 100 $\mathrm{m} M \mathrm{dNTP}, 0.2 \mathrm{~m} M$ of each primer, and $100 \mathrm{ng}$ of DNA template. The DNA amplification of see, selg, selh, and seli was carried out as follows: $95^{\circ} \mathrm{C}$ for 5 min, 35 cycles of $95^{\circ} \mathrm{C}$ for $30 \mathrm{~s}, 53^{\circ} \mathrm{C}$ for $90 \mathrm{~s}$, and $72^{\circ} \mathrm{C}$ for $90 \mathrm{~s}$, with a final extension at $72^{\circ} \mathrm{C}$ for $10 \mathrm{~min}$. The DNA amplification of the selj, selm, seln, and selo group and the selk,

Table 1. Primers for the V5 region of the $16 \mathrm{~S}$ rDNA sequencing and PCR or real time reverse transcription-PCR tests targeting the classical and newly described staphylococcal enterotoxin genes

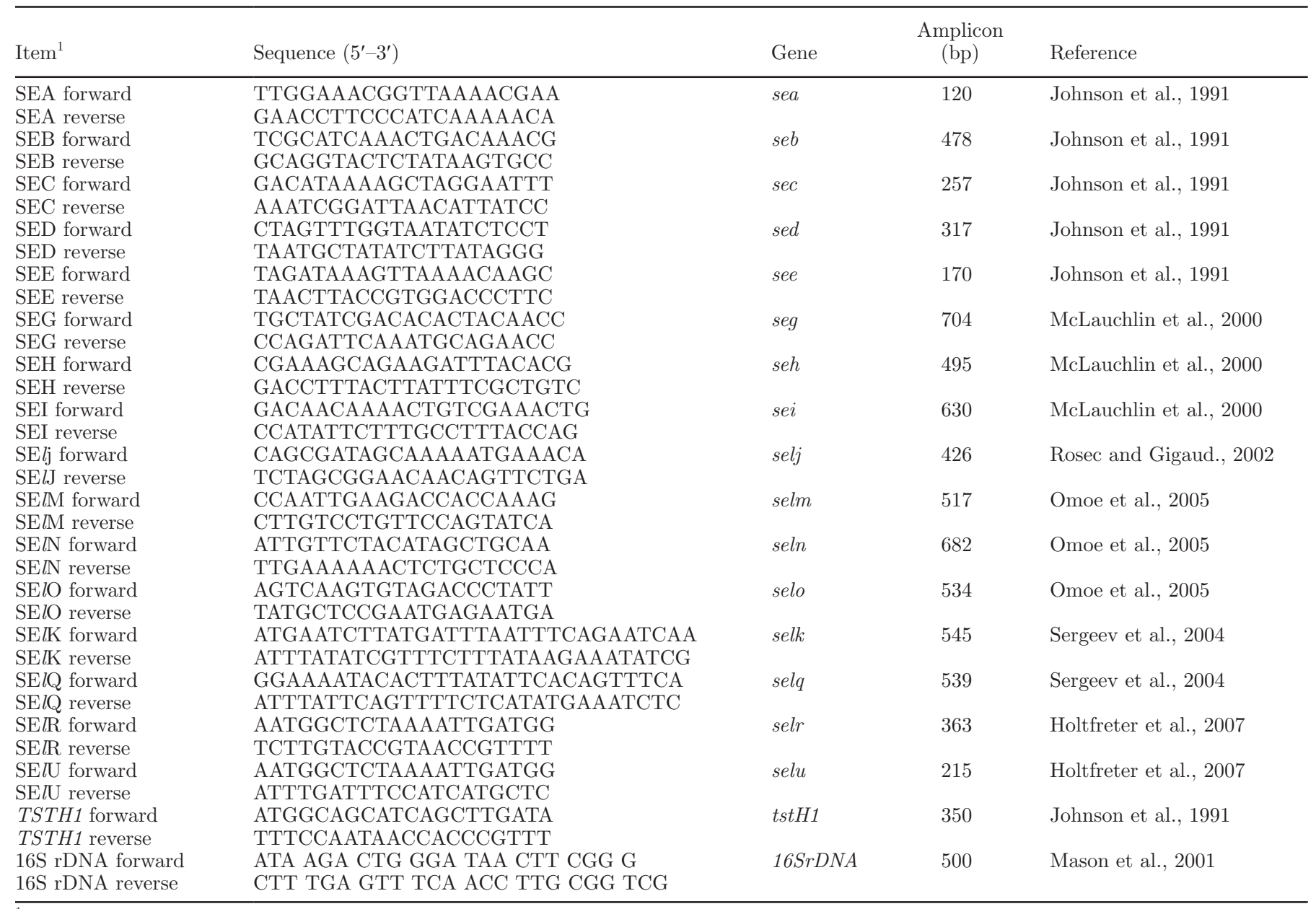

${ }^{1} \mathrm{Se}=$ enterotoxins; $\mathrm{SE} l=$ SE-like toxins. 
selq, selr, and selu group were carried out in the same conditions: $95^{\circ} \mathrm{C}$ for $5 \mathrm{~min}$, followed by 35 cycles at $95^{\circ} \mathrm{C}$ for $30 \mathrm{~s}, 55^{\circ} \mathrm{C}$ for $90 \mathrm{~s}$, and $72^{\circ} \mathrm{C}$ for $90 \mathrm{~s}$, with a final extension at $72^{\circ} \mathrm{C}$ for $10 \mathrm{~min}$ (Omoe et al., 2005). The PCR products were visualized by electrophoresis on 1.2\% agarose gels (Uniscience do Brasil, São Paulo, Brazil) in $1 \times$ TAE (Tris-acetate-EDTA) buffer stained by $0.5 \mu \mathrm{g} / \mathrm{mL}$ of GelRed (BioAmerica) and documented on a transilluminator (MiniLumi Imaging Bio-Systems, BioAmerica).

\section{Enterotoxin Expression Assays}

The isolated strains were cultured overnight aerobically in $10 \mathrm{~mL}$ of brain heart infusion broth (BD BBL) at $37^{\circ} \mathrm{C}$ for $72 \mathrm{~h}$. Bacteria supernatants were collected by centrifugation at $4,000 \times g$ for $10 \mathrm{~min}$ at room temperature and used for the detection of SEA, SEB, SEC, SED, and SEE in an ELISA using a commercial detection kit (Ridascreen Set A, B, C, D, E Art. No: R4101, R-Biopharm AG, Darmstadt, Germany). The assay was performed according to the manufacturer's recommendation and as described elsewhere (Rahimi and Ghasemian Safai, 2010). The mean lower limit of detection of the assay was $0.25 \mathrm{ng} / \mathrm{mL}$. The threshold was defined as the average optical density of 2 negative controls plus 0.15 , a constant established by the kit. Samples containing SE showed absorbance values equal or greater than the threshold value. All experiments were performed in duplicate.

\section{Real Time Reverse Transcription-PCR Assays}

Total RNA was extracted by using the Qiagen Ribopure TM Bacteria kit (Life Technologies, Carlsbad, $\mathrm{CA}$ ) following the manufacturer's instructions and quantified using the Qubit fluorimeter and Qubit assay kits (Invitrogen).

The cDNA synthesis was performed by using the High Capacity cDNA Reverse Transcription Kit (Applied Biosystems) as follows: $4.0 \mu \mathrm{g}$ of RNA, $2.0 \mu \mathrm{L}$ of $10 \times$ reverse transcription (RT) buffer, $0.8 \mu \mathrm{L}$ of $\mathrm{dNTP}$ $\operatorname{mix}(100 \mathrm{mM}), 2.0 \mu \mathrm{L}$ of $10 \times \mathrm{RT}$ random primers, 1.0 $\mu \mathrm{L}$ of MultiScribe (Applied Biosystems, Foster City, $\mathrm{CA}$ ) reverse transcriptase, and $4.2 \mu \mathrm{L}$ of nuclease-free $\mathrm{H}_{2} \mathrm{O}$. The cDNA synthesis was performed under the following conditions: step 1 at $25^{\circ} \mathrm{C}$ for $10 \mathrm{~min}, 37^{\circ} \mathrm{C}$ for $120 \mathrm{~min}$, and $85^{\circ} \mathrm{C}$ for $5 \mathrm{~min}$ in an ABI Prism 7500 Fast RT-PCR system (Applied Biosystems). Samples were plated in triplicate in 96-well plates where $12 \mu \mathrm{l}$ of the SYBR Green PCR Master Mix, $1 \mu \mathrm{L}$ of primer mix (sea, seb, sec, sed, see, seg, seh, sei, selj, selm, seln, selo, selq, selr, selu, or tstH1; Table 1), and 4.5 $\mu \mathrm{L}$ of the cDNA ultrapure water were added to each well. Amplification was performed under the following conditions: $95^{\circ} \mathrm{C}$ for $15 \mathrm{~min}, 40$ cycles at $95^{\circ} \mathrm{C}$ for $15 \mathrm{~s}$, $54^{\circ} \mathrm{C}$ for $30 \mathrm{~s}$, and $72^{\circ} \mathrm{C}$ for $30 \mathrm{~s}$. The dissociation curve was performed at $95^{\circ} \mathrm{C}$ for $15 \mathrm{~s}, 54^{\circ} \mathrm{C}$ for $30 \mathrm{~s}$, and $95^{\circ} \mathrm{C}$ for $15 \mathrm{~s}$. The DNA templates from reference strains $S$. aureus ATCC 29231 (sea), S. aureus ATCC 14458 (seb, tsst, selk, selq, selr, and selu), S. aureus ATCC 19095 (sec, seg, seh, and sei), S. aureus ATCC 13563 (sed), S. aureus ATCC 27664 (see), and S. aureus ATCC 27154 (selj, selm, seln, and selo) were used as controls. Gene expression was estimated by the semi quantification of mRNA (arbitrary units) in comparison with the mRNA content from reference strains. Messenger 16S rDNA was used as an internal control to normalize enterotoxin expression levels. Cycle threshold value estimations, the standard deviations, and the cDNA quantification were calculated using the GraphPad Prism 5 software package (GraphPad Software Inc., La Jolla, CA). Calibration curves based on 5 points were constructed in triplicate corresponding to serial dilutions $(1,1: 10$, 1:100, 1:1,000 and 1:10,000) from $100 \mathrm{ng}$ of a DNA template stock solution.

\section{Antibiotic Susceptibility Tests}

An inoculum of each isolated strain equivalent to 0.5 McFarland scale was swabbed onto the Muller Hinton agar plate (BD BBL) and the antibiotic disc was then placed on the plate followed by overnight incubation at $37^{\circ} \mathrm{C}$. The inhibition zone was interpreted according to the Clinical Laboratory Standards Institute (CLSI, 2014) guidelines (formerly known as the National Committee for Clinical Laboratory Standards). The tested antibiotics were penicillin $\mathrm{G}(10 \mu \mathrm{g})$, oxacillin $(1 \mu \mathrm{g})$, neomycin $(30 \mu \mathrm{g})$, trimethoprim $(5 \mu \mathrm{g})$, clindamycin $(2$ $\mu \mathrm{g})$, gentamicin $(10 \mu \mathrm{g})$, cefetoxin $(30 \mu \mathrm{g})$, rifampicin $(5 \mu \mathrm{g})$, erythromycin $(15 \mu \mathrm{g})$, tetracycline $(30 \mu \mathrm{g})$, vancomycin $(30 \mu \mathrm{g})$, ciprofloxacin $(5 \mu \mathrm{g})$, sulfazothrim (23 $\mu \mathrm{g})$, cefepime $(30 \mu \mathrm{g})$, and linezolid $(30 \mu \mathrm{g})$.

\section{MIC Determinations}

Minimum inhibitory concentrations for vancomycin, linezolid, methicillin, and ampicillin were determined by the macrodilution broth method based on CLSI recommendations, using in-house-prepared panels (NCCLS, 2003). Antibiotic concentrations of 0.03, 0.06, $0.125,0.25,0.5,1.0$, and $2.0 \mathrm{mg} / \mathrm{mL}$ were tested. One milliliter of broth was transferred to the tubes and 100 $\mu \mathrm{L}$ of bacteria suspension was adjusted to $10^{6} \mathrm{cfu} / \mathrm{mL}$ in saline solution $0.85 \%$ according to $0.5 \mathrm{McF}$ arland scale and transferred to tubes containing $1 \mathrm{~mL}$ of each diluted antimicrobial. Isolated strains were grown in Mueller-Hinton broth (BD BBL) and the MIC was 
estimated as the lowest antibiotic concentration that inhibits visible growth after $24 \mathrm{~h}$ (NCCLS, 2003).

\section{RESULTS AND DISCUSSION}

\section{Isolation and Identification of CNS from Minas Frescal}

Sixty suggestive CNS microorganisms were isolated from Minas Frescal cheese by colony morphology, the coagulase slide test, subsequent tube test, and biochemical tests. After these tests, 45 strains were submitted to sequencing of the $\mathrm{V} 5$ region of the $16 \mathrm{~S} \mathrm{rDNA}$, and the alignment of sequences to those available in GenBank was discriminative enough to differentiate 42 Staphylococcus strains isolated from Minas Frescal at the species level and 1 to the subspecies level with similarities $>98 \%$. Three strains were confirmed as belonging to the Staphylococcus genera ( the 42 staphylococci were identical to each other and 10 distinct strains were considered. The 10 distinct strains were grouped into 4 Staphylococcus species, where the predominant species was $S$. saprophyticus with 4 strains (40\%), followed by 3 of S. xylosus strains, (30\%), 2 of S. sciuri strains (20\%), and 1 of S. piscifermentans strain (10\%). A single isolated strain, Staphylococcus saprophyticus bovis KT955013, was identified to the subspecies level (98\% similarity; Table 2).

According to previous reports, the predominant species found in Minas Frescal cheese are Staphylococcus equorum, S. lentus, Staphylococcus simulans, S. sciuri, and S. xylosus (Ruaro et al., 2013), but S. saprophyticus, S. epidermidis, in addition to $S$. equorum, were also found in the dairy products of a small Portuguese ewes (Soares et al., 2011). However, S. equorum, S. xylosus, S. saprophyticus, and $S$. succinus were the most prevalent species in French cheeses (Coton et al., 2010). In the present study, Staphylococcus equorum, S. lentus, S. simulans, S. epidermidis, and S. succinus were not found in Minas Frescal cheese, but as 3 staphylococci strains were not identified up to the species level, perhaps some of these could be among the species isolated from Minas Frescal cheese. The stability of the biodiversity of the consortia found in Minas Frescal cheese is in accordance with the one already described for red-smear cheese (Rea et al., 2007), but great diversity among CNS can be found if the microbiota of distinct cheese matrices are compared (Dobranic et al., 2013).

\section{Phylogenetic Relationships of CNS Isolated from Minas Frescal Cheese}

The 10 distinct CNS strains isolated from Minas Frescal cheese showed little diversity when compared with staphylococci microbiota from different food matrices (Figure 1), perhaps due to the unique features of the cheese studied. The 10 distinct CNS strains can be grouped in 3 species sets: saprophyticus, sciuri, and simulans. Frequently, the saprophyticus species group includes $S$. xylosus and $S$. saprophyticus; the simulans species group comprises $S$. carnosus and $S$. piscifermentans; and the sciuri species group contains $S$. sciuri, S. lentus, and S. pasteuri (Lamers et al., 2012). In the present study, the main cluster comprised $S$. saprophyticus KT955013, KT955010, KT955007, and S. xylosus KT955011, both grouped with S. piscifermentans KT955006, a species that is phylogenetically related to the simulans species group, as already established. Staphylococcus sciuri KT955004, a species belonging to the sciuri species group, was clustered with $S$. $x y$ losus KT955012. The third cluster includes S. sciuri JX966436.1, S. xylosus KT955008, and S. saprophyticus KT955005 (Figure 1).

The close similarities between S. sciuri KT955004 and $S$. xylosus KT955012 as well as S. saprophyticus KT955005 and S. xylosus KT955008 are supported by a bootstrap value of $100 \%$. The interspecies similarities were superior to $90 \%$, which demonstrates the close phylogenies among the CNS strains isolated from Minas Frescal cheese.

\section{Genotypic and Phenotypic Characterization of CNS Strains from Minas Frescal}

In the present study, 9 distinct combinations of staphylococcal enterotoxin genes were found in the $10 \mathrm{CNS}$ strains, comprising the SE A to E, G to J, as well as the SEl K to R and U (Table 2). The sea and seb genes showed high prevalence, in which the sea gene was the most predominant, carried by $90 \%$ of strains, followed by seb, carried by $70 \%$ of the genomes. Genes sec, sed, see, she, and sei showed intermediary prevalence, where see and sec were carried by $60 \%$ of the isolated strains, seh and sei were found in 50\% of the strains, and sed in $40 \%$ of the strains. Finally, seg, selk, selq, selr, and selu showed low prevalence, being carried by $20 \%$ of the CNS strains (Table 2); no tstH1 gene was found.

Although studies on the emerging enterotoxins in Brazilian milk or dairy-derived products have not yet been reported, the frequency of the enterotoxin genes encoding the classical enterotoxins set SEA to SED in Minas Frescal cheeses can be compared with those described for the CNS microbiota of bulk bovine milk from a recent study (de Freitas Guimarães et al., 2013), which found that the sea gene is carried by $35.1 \%$ of the strains, seb by $7.1 \%$, and sec by $6.5 \%$. Even considering only the classical enterotoxin genes, Minas Frescal cheese seems to comprise a CNS microbiota with higher 
COAGULASE-NEGATIVE STAPHYLOCOCCI IN MINAS FRESCAL

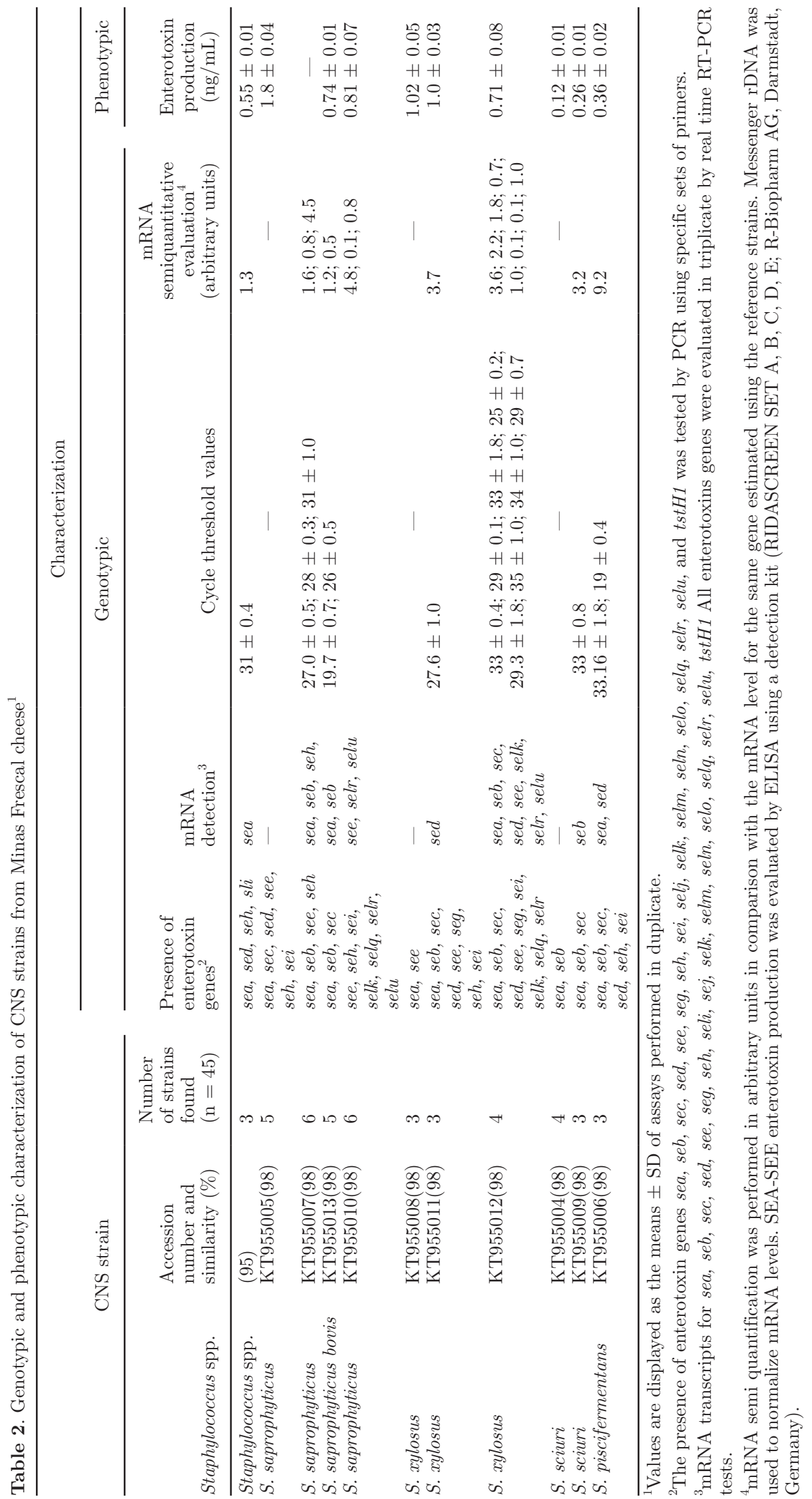




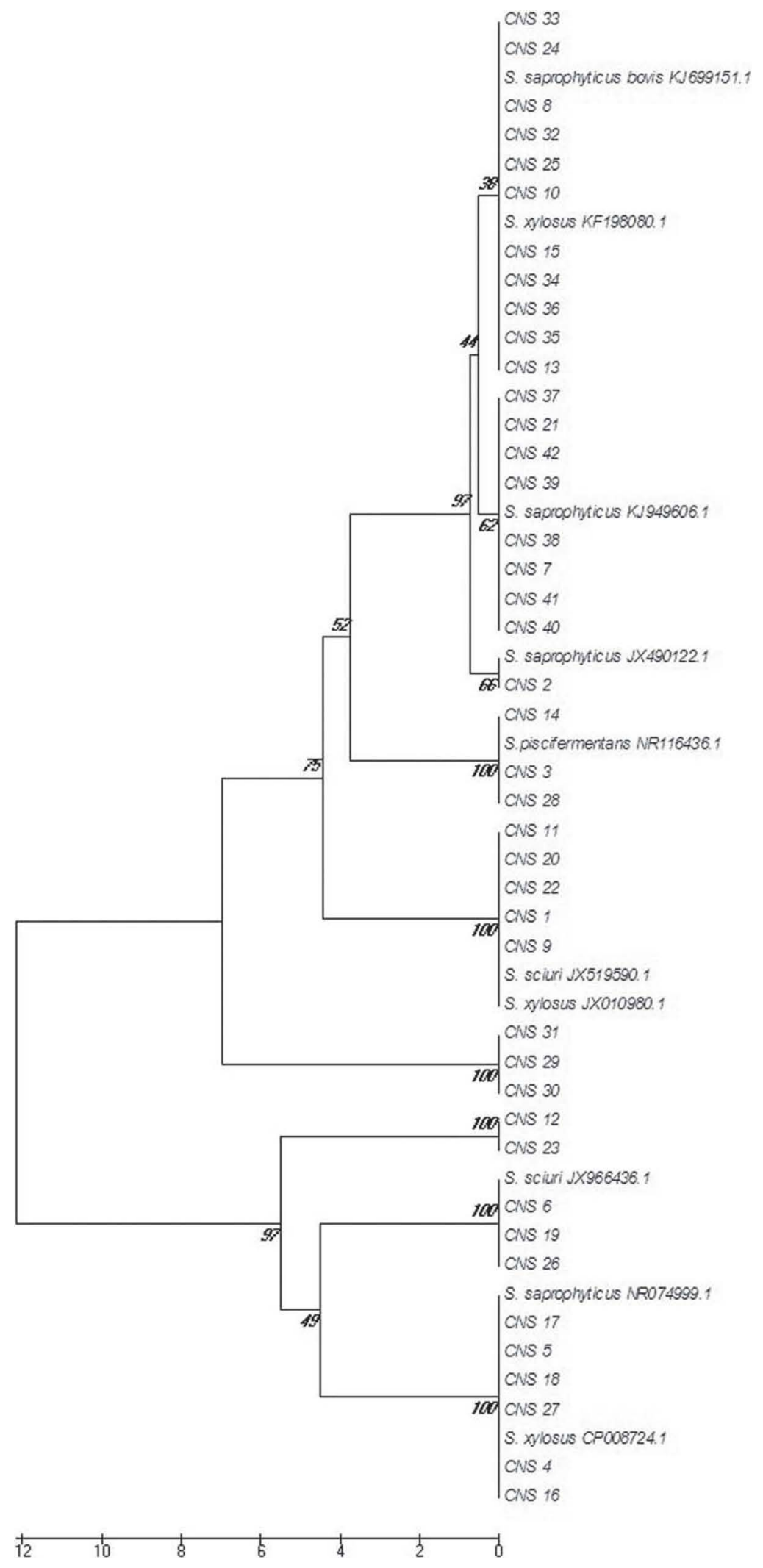

Figure 1. Phylogenetic trees generated from the multiple alignment of $16 \mathrm{~S}$ rDNA sequences from the 42 CNS strains found in Minas frescal cheese. The Clustal X 2.0 software (Larkin et al., 2007) using Mega 6.0 and the unweighted pair group method (UPGMA) were used. Bootstrap values ranged from 0.0 to 0.3 . 
biodiversity and superantigenic toxin genes and, at the same time, with high phylogenetic relationships between them. This disagreement regarding the CNS microbiota of bulk bovine milk and Minas Frescal cheese may be due to contamination with other staphylococci strains from the environment or human origin acquired during the cheese manufacturing process.

Following the identification of the staphylococcal enterotoxins SEG and SEI by Munson et al. (1998), Monday and Bohach (2001), and Jarraud et al. (2001), it has been reported that the genes encoding these enterotoxins are part of a chromosomal operon, termed the enterotoxin gene cluster $(e g c)$, comprising 5 genes designated selo, selm, sei, seln, and seg. Two CNS S. xylosus strains in the present study-KT955011 and KT955012 - were shown to carry the seg and sei genes, and in 2 strains of $S$. saprophyticus, KT955005 and KT955010, a single sei gene sequence was detected. The presence of part of the genes and not the entire egc operon may be due to the high degree of genetic polymorphism in the chromosomal assembly (Thomas et al., 2006). Subsequently, Letertre et al. (2003) demonstrated that some egc clusters possess an additional gene designated selu. Indeed, the S. saprophyticus KT955010 strain carries the selu gene clustered to the sei gene. The selm, seln, and selo genes were not found in the CNS genomes of Minas Frescal cheese strains. The CNS strains clustered in groups near the bottom of the phylogenetic tree carried the classical enterotoxin genes and the species at the top of the tree showed high diversity among enterotoxin genes, combining the presence of classical and the newly described in their genomes (Figures 1 and 2 and Table 2).

To assess the risk of Minas Frescal related to staphylococcal food poisoning, the ability of those strains carrying the se and sel genes in their genome in expressing and producing enterotoxins was evaluated. The mRNA transcripts for each enterotoxin gene was evaluated by real-time reverse transcription PCR assays and the enterotoxin production was estimated by a sandwich enzyme immunoassay for the combined detection of Staphylococcus enterotoxins A, B, C, D and E.

Nine CNS strains from Minas Frescal cheese were able to produce the classical enterotoxins SEA, SEB, SEC, SED, and SEE during growth, in concentrations ranging from 0.12 to $1.8 \mathrm{ng} / \mathrm{mL}$ (Table 2). Although the sandwich enzyme immunoassay is considered the most sensitive method to detect SEA to SEE enterotoxins, able to detect $0.125 \mathrm{ng} / \mathrm{mL}$, differences in the specificity and sensitivity of the assays for the detection of staphylococcal enterotoxins from foods are expected (Pereira et al., 2009). Only a single strain, S. saprophyticus KT955005, was unable to produce SEA to SEE enterotoxins when evaluated by this assay.
The mRNA for at least 1 enterotoxin gene was detected in 7 strains $(70 \%)$ and, additionally, 5 of them $(50 \%)$ were able to transcribe multiple enterotoxin genes in vitro. Strains S. saprophyticus KT955007, S. bovis saprophyticus KT955013, S. saprophyticus KT955010, S. xylosus KT955012, and S. piscifermentans KT955005 expressed mRNA for multiple se genes. A differential transcription among the se genes was observed, where the most frequently transcribed among the classical were sea and seb, transcribed by 4 strains, and, among the newly described, selk, selr, selu, were transcribed by 2 strains each; no mRNA tstH1 was detected.

No mRNA transcripts were detected in the $S$. saprophyticus KT955005, S. xylosus KT955008, or S. sciuri KT955004 strains assayed, although the enterotoxins were detected by the enzyme-linked immune-sorbent tests. The genotypic and phenotypic analyses pointed to a high risk of food poisoning in consuming Minas Frescal cheese contaminated by the CNS strains identified in the present study. The food poisoning status of Minas Frescal cheese can be acquired even during cheese manufacturing, because CNS strains are able to express and produce enterotoxins at the early stage of logarithmic growth. The presence of enterotoxigenic strains in a ready-to-eat dairy product is of concern and underlines the need for standardized diagnostic methods to screen for and quantify the presence of classical and also emergent enterotoxins directly in the food matrices.

The use of real-time reverse transcription PCR assays conferred sensitivity and specificity for the determination of the enterotoxin gene transcription, besides the additional ability to evaluate the expression of all enterotoxin genes encoding both the classical and newly described super antigenic enterotoxins. The real-time reverse transcription PCR tests also avoided the false positives that occur in immunoassays by cross-reactions between the classical polyclonal antibodies and the newly described enterotoxins.

\section{Multiresistance of CNS Strains to Antimicrobial Agents}

The 10 distinct CNS strains (plus Staphylococcus spp.) from Minas Frescal cheese showed multiresistance to several antimicrobial agents. Five strains showed multiple antimicrobial resistance (MAR) indexes from 0.73 to 0.93 , two strains presented MAR indexes of 0.53 and 0.40 , and the remaining 3 strains showed a MAR index of 0.26 (Table 3 ).

The resistance of the 10 multiresistance of CNS strains (MRCNS) was distributed as follows: 6 strains (60\%) were resistant to sulfamethoprim, 5 strains (50\%) 
to aminoglycosides (ciprofloxacin, neomycin, or gentamicin), 6 strains (60\%), to chloramphenicol, 8 strains $(80 \%)$ to vancomycin, 5 strains $(50 \%)$ to clindamycin, 10 strains $(100 \%)$ to $\beta$-lactams (oxacillin, penicillin, or cefoxitin), 6 strains $(60 \%)$ to tetracyclines (tetracycline or rifampicin), 3 strains (30\%) to cefepime, 5 strains to erythromycin (50\%), and 3 strains $(30 \%)$ to linezolid (Table 3).
The percentage of MRCNS resistant to $\beta$-lactams was superior to that found by Sampimon et al., (2011), which showed that only $14 \%$ of the 170 staphylococci from raw milk obtained from various ruminant species were resistant to penicillin. It should be considered that the contamination by resistant strains could occur later, during cheese processing, by improper handling or sanitization of the production line in industrial plants,

A

B



Figure 2. Uniplex, duplex and multiplex-PCR screening to detect enterotoxin genes in CNS strains from Minas Frescal cheese. The DNA templates obtained from 11 CNS strains isolated from Minas Frescal cheese were tested by PCR using the primer set targeting for sea, seb, sec, sed, see, seg, seh, sei, selk, selq, selr, and selu genes. (A) Lane M 100 bp = DNA ladder plus (Fermentas, Foster City, CA); lane ATCC 29231 $=$ Staphylococcus aureus ATCC 29231 carrying sea gene; lane ATCC19095 = S. aureus ATCC19095 carrying the sec gene; lane ATCC13563 $=S$. aureus ATCC 13563 carrying the sed gene; lane ATCC27664 = S. aureus ATCC27664 carrying the see gene. (B) Lane M $100 \mathrm{bp}=\mathrm{DNA}$ ladder plus; lane ATCC $19095=S$. aureus ATCC 19095 carrying seg seh sei genes. (C) Lane M 100 bp = DNA ladder plus; lane JX114799.1 = Staphylococcus spp. JX114799.1: lanes KT955005 = Staphylococcus saprophyticus KT955005: lane KT955008 = Staphylococcus xylosus KT955008; lane KT955007 = S. saprophyticus KT955007. (D) Lane M 100 bp = DNA ladder plus; lane KT955007 = S. saprophyticus KT955007; lane KT955004 = Staphylococcus sciuri KT955004; lane KT955009 = S. sciuri KT955009. (E) Lane M 100 bp = DNA ladder plus; lane KT955013 $=$ S. saprophyticus KT955013; lane KT955012 = S. xylosus KT955012. (F) Lane ATCC 14458 = S. aureus ATCC 14458 carrying selk, selq, selr and selu gene; lanes KT955010 = S. saprophyticus KT955010. 
reinforcing the difference between the CNS microbiota from bulk milk and dairy-derived products, as discussed previously.

Surprisingly, the resistance to chloramphenicol was very similar to that estimated for MRCNS strains isolated from human clinical samples (Knauer et al., 2004), reinforcing the fact that the multi-resistance character of the food matrices strains must be taken in consideration when evaluating the safety hazards of food poisoning.

The MRCNS isolated in the present study showed superior resistance to $\beta$-lactam compared with other antimicrobials, as all isolates were resistant to at least 1 antimicrobial agent belonging to this class of compounds. Fifty to sixty percent of the strains were resistant to aminoglycosides, clindamycin, ciprofloxacin, and sulfamethoprim.

To determine the MIC for ampicillin and methicillin, oxacillin, or cefoxitin, all susceptible CNS strains found in Minas Frescal cheese were tested using the macrodilution broth method. The resistant strains were tested against concentrations ranging from 0.03 to $2 \mathrm{mg} / \mathrm{mL}$ of each antimicrobial agent.

Concerning methicillin-resistance, S. saprophyticus KT955010, S. piscifermentans KT955006, S. saprophyticus bovis KT955013, and S. xylosus KT955012 showed MIC values of $1.0 \mathrm{mg} / \mathrm{mL}$. Staphylococcus xylosus KT955012 and S. piscifermentans KT955006 strains presented a MIC value of $0.5 \mathrm{mg} / \mathrm{mL}$, whereas S. sciuri KT955009 and S. xylosus KT955011 strains had a MIC value of $0.06 \mathrm{mg} / \mathrm{mL}$. The remaining strains were susceptible to $0.03 \mathrm{mg} / \mathrm{mL}$ of methicillin, ampicillin, and vancomycin.

Concerning resistance against ampicillin, the $S$. xylosus KT955008 strain was shown to be resistant to 0.5 $\mathrm{mg} / \mathrm{mL}$, whereas S. xylosus KT955012, S. saprophyticus bovis KT955013, and S. piscifermentans KT955006 were resistant to $0.125 \mathrm{mg} / \mathrm{mL}$, and $S$. sciuri KT955004, S. xylosus KT955011, and S. xylosus KT955012 were resistant to $0.06 \mathrm{mg} / \mathrm{mL}$. The MIC estimated in our study were in accordance to a previous evaluation of the resistance of $S$. aureus strains isolated from meat, dairy products, and ready-to-eat food (Aydin et al., 2011), which showed MIC values of $0.03 \mathrm{mg} / \mathrm{mL}$ for penicillin estimated for 91 isolated strains.

The high resistance observed in the present study for cheese staphylococci can be due to the inappropriate use as growth promoters of some antimicrobial agents, such as oxacillin, vancomycin, chloramphenicol, neomycin, and erythromycin, which are commonly used in veterinary medicine to treat infections (Phillips et al., 2004). Antimicrobial resistance of staphylococci in dairy products could be the result of the incorrect use of penicillin in the treatment and prevention of mastitis in different ruminant animals (Sampimon et al., 2011).

The resistance of the isolated CNS to antibiotics of therapeutic importance has become a public health problem, as the manufacturing processes of Minas Frescal cheese cannot kill the strains or inactivate the toxins. This makes an apparently safe food the cause of serious gastroenteritis with the ability to disseminate pathogens with multiresistance to antibiotic therapy.

Table 3. Multiple antimicrobial resistance of CNS strains found in Minas Frescal cheese

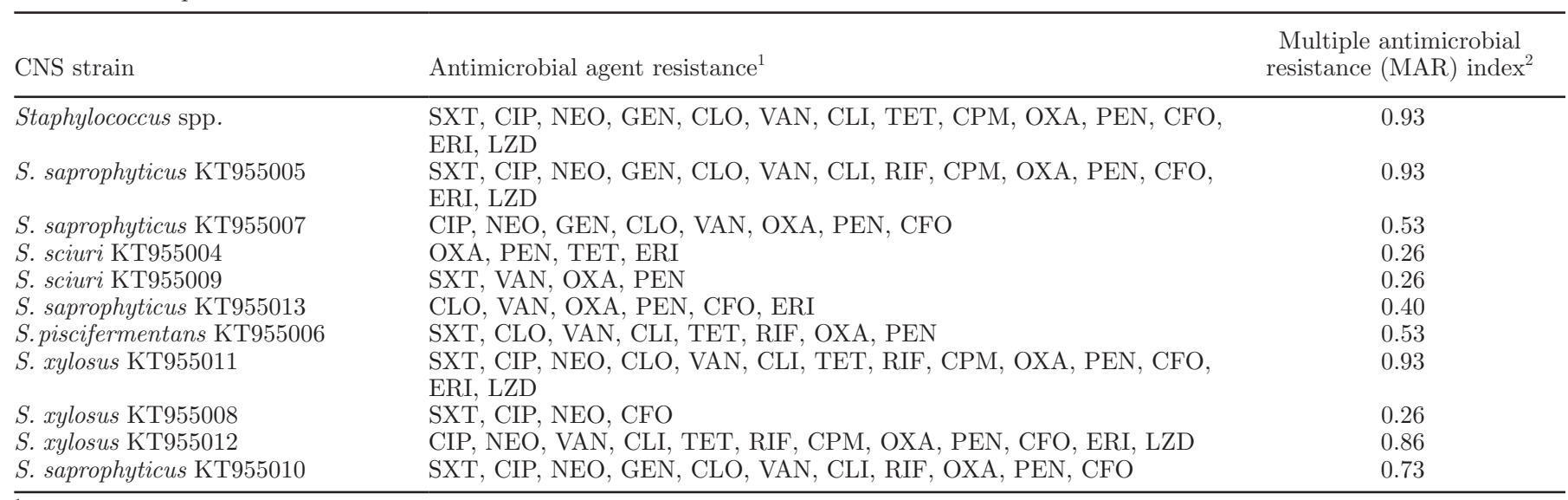

${ }^{1} \mathrm{SXT}=$ sulfamethoprim; $\mathrm{CIP}=$ ciprofloxacin; $\mathrm{NEO}=$ neomycin; $\mathrm{GEN}=$ gentamicin; $\mathrm{CLO}=$ chloramphenicol; $\mathrm{CLI}=$ clindamycin; $\mathrm{VAN}=$ vancomycin; TET = tetracycline; $\mathrm{RIF}=$ rifampicin; $\mathrm{CPM}=$ cefepime; OXA $=$ oxacillin; $\mathrm{PEN}=$ penicillin; $\mathrm{CFO}=$ cefoxitin; $\mathrm{ERI}=$ erythromycin; LZD = linezolid.

${ }^{2}$ The MAR index of an isolate is defined as $\mathrm{a} / \mathrm{b}$, where a represents the number of antimicrobials to which the isolate was resistant to and $\mathrm{b}$ represents the number of antimicrobials to which the isolate was subjected to. Staphylococcus aureus strains ATCC WB81 (sea), ATCC 13563 (sed), ATCC 27664 (see) with MAR index $=0.5$ and S. aureus strains ATCC14458 (seb), ATCCWB72 (sec) and S. xylosus ATCC 29971 with MAR index $=0.3$ were used as reference strains. 
The safety of Minas Frescal cheese consumption could also be enhanced by the inclusion of a microbial barrier, such as the inclusion of probiotic strains producing natural antibiotics, competitive flora, or even the addition of natural bioagents against spoilage or pathogenic microorganisms. In situ bacteriocin production by lactic acid bacteria, acting as adjunct or protective culture, could be an effective strategy to avoid staphylococcus food poisoning in Minas Frescal cheese. The use of a probiotic bacteria in the cheese processing should enhance the cost of the product and at the same time add value to the cheese, as it becomes richer in organoleptic and nutritional properties but can be priced as being naturally preserved.

\section{CONCLUSIONS}

The staphylococci contamination of Minas Frescal cheese can occur by inadequate manufacturing practices or inadequate storage conditions, use of contaminated milk, or even due to the physico-chemical features of the cheese matrix favorable to the growth of these microorganisms. In addition, the CNS strains are also able to produce enterotoxins. The additional safety hazards associated with these strains mostly include antimicrobial resistance to the compounds commonly used to treat staphylococci infections. Antimicrobial resistance of CNS strains from food matrices can spread in populations by the consumption of an apparently safe food. The detection and quantification of enterotoxins in cheese matrices produced by those CNS strains should be evaluated.

\section{ACKNOWLEDGMENTS}

The authors acknowledge the financial support from Fundação Carlos Chagas Filho de Amparo à Pesquisa do Estado do Rio de Janeiro (FAPERJ, Rio de Janeiro, Brazil), Conselho Nacional de Desenvolvimento Científico e Tecnológico (CNPq, Brasília, Brazil) and Coordenação de Aperfeiçoamento de Pessoal de Nível Superior (CAPES, Brasília, Brazil).

\section{REFERENCES}

Almeida, K. E., A. Y. Tamine, and M. N. Oliveira. 2008. Acidification rates of probiotic bacteria in Minas frescal cheese whey. LWT Food Sci. Technol. (Campinas.) 41:311-316.

Argudin, M. A., M. C. Mendoza, and M. R. Rodicio. 2010. Food poisoning and Staphylococcus aureus and enterotoxins. Toxins 2:17511773.

Aydin, A., K. Muratoglu, M. Sudagidan, K. Bostan, B. Okuklu, and S. Harsa. 2011. Prevalence and antibiotic resistance of foodborne Staphylococcus aureus isolates in Turkey. Foodborne Pathog. Dis. 8:63-69.

Brasil. 1997. Regulamento técnico para fixação de identidade e qualidade de queijo Minas Frescal. Portaria n 352 . Seção I, pages 13-68
Diário Oficial da União. Ministério da Agricultura, Pecuária e Abastecimento, Brasília, Brazil.

Brasil. 2001 Regulamento Técnico sobre padrões microbiológicos para alimentos. Resolução RDC n 12, de 02 de janeiro de 2001. Diário Oficial da União. Ministério da Saúde, Agência Nacional de Vigilância Sanitária, Brasília, DF, Brazil.

Bulhões, C. C. C., and O. D. Rossi Junior. 2002. Ocorrência de bactérias do gênero Aeromonas em queijo-de-Minas frescal artesanal Arq. Bras. Med. Vet. Zootec. 54:320-324.

Campos, D. C. 2001. Queijo: Breve Histórico e Principais Características. Núcleo de Apoio à Pesquisa em Microbiologia Agrícola/ ESALQ, Piracicaba, Brazil

Cichoscki, A. J., E. Valduga, A. T. Valduga, M. E. Tornadijo, and J. M. Freno. 2002. Characterization of Prato cheese, a Brazilian semi-hard cow variety: evolution of physico-chemical parameters and mineral composition during ripening. Food Contr. 13:329-336.

CLSI. 2014. Performance Standards for Antimicrobial Susceptibility Testing: 24th Informational Supplement. CLSI document M100S24. Clinical and Laboratory Standards Institute (CLSI), Wayne, $\mathrm{Pa}$.

Coton, E., M. H. Desmonts, S. Leroy, M. Coton, E. Jamet, and S. Christieans. 2010. Biodiversity of coagulase-negative staphylococci in French cheeses, dry fermented sausages, processing environments and clinical samples. Int. J. Food Microbiol. 137:221-229.

Dobranic, V., N. Zdolec, I. Racic, A. Vujnovic, M. Zdelar-Tuk, I Filipovic, N. Grgurev, and S. Spicic. 2013. Determination of enterotoxin genes determination of enterotoxin genes in coagulasenegative staphylococci from autochthonous Croatian fermented sausages. Vet. Arhiv 83:145-152.

de Freitas Guimarães, F., D. B. Nóbrega, V. B. Richini-Pereira, P. M. Marson, J. C. Figueiredo Pantoja, and H. Langoni. 2013. Enterotoxin genes in coagulase negative and coagulase-positive staphylococci isolated from bovine milk. J. Dairy Sci. 96:2866-2872.

Garrity, G., D. J. Brenner, N. R. Krieg, and J. R. Staley. 2005. Bergey Manual $^{\circledR}$ of Systematic Bacteriology, ed. 2. Springer Plus.

Holtfreter, S., D. Grumann, M. Schmudde, H. T. T. Nguyen, P. Eichler, B. Strommenger, K. Kopron, J. Kolata, and S. Giedrys-Kalemba. 2007. Clonal distribution of superantigen genes in clinical Staphylococcus isolates. J. Clin. Microbiol. 45:2669-2680.

ICMSF. 1983. Ecologia Microbiana de los Alimentos 1. Factores que Afectan a la Supervivencia de los Microorganismos em los Alimentos. Editorial Acribia, Zaragoza, Spain.

ICMSF. 2006. Use of Epidemiologic Data to Measure the Impact of Food Safety Control Programs. International Commission on Microbiological Specifications for Foods (ICMSF), North Ryde, Australia.

Jarraud, S., M. A. Peyrat, A. Lim, A. Tristan, M. Bes, C. Mougel, J. Etienne, F. Vandenesch, M. Bonneville, and G. Lina. 2001. egc a highly prevalent operon of enterotoxin gene, forms a putative nursery of superantigens in Staphylococcus aureus. J. Immunol. 166:669-677.

Johnson, W. M., S. D. Tyler, E. P. Ewan, F. E. Ashton, D. R. Pollard, and K. R. Rozee. 1991. Detection of genes for enterotoxins, exfoliative toxins, and toxin shock syndrome toxin 1 in Staphylococcus aureus by the polymerase chain reaction. J. Clin. Microbiol. 29:426-430

Kamiyama, C. M., and M. H. Otenio. 2013. Aspects of water quality and quality of products in the dairy industry. Rev. Inst. Laticínios Cândido Tostes. Juiz de Fora 68:42-50.

Kästner, M., A. Fischer, I. Nijenhius, R. Geyer, N. Stelzer, P. Bombach, C. C. Tebbe, and H. H. Richnow. 2006. Assessment of microbial in situ activity in contaminated aquifers. Eng. Life Sci. 6:234-251.

Knauer, A., P. Fladerer, and C. Strempfl. 2004. Effect of hospitalization and antimicrobial therapy on bantimicrobial resistance of colonizing Staphylococcus epidermidis. Wien. Klin. Wochenschr. 116:489-494.

Lamers, A. P., M. E. Keithly, K. Kim, P. D. Cook, D. F. Stec, K. M. Hines, G. A. Sulikowski, and R. N. Armstrong. 2012. Synthesis of bacillithiol and the catalytic selectivity of FosB-type fosfomycin resistance proteins. Org. Lett. 14:5207-5209. 
Larkin, M. A., G. Blackshields, N. P. Brown, R. Chenna, P. A. McGettigan, H. McWilliam, F. Valentin, I. M. Wallace, A. Wilm, R. Lopez, J. D. Thompson, T. J. Gibson, and D. G. Higgins. 2007. Clustal W and Clustal X version 2.0. Bioinformatics 23:2947-2948.

Letertre, C., S. Perelle, F. Dilasser, and P. Fach. 2003. Identification of a new putative enterotoxin SEU encoded by the egc cluster of Staphylococcus aureus. J. Appl. Microbiol. 95:38-43.

Lina, G., G. A. Bohach, S. P. Nair, K. Hiramatsu, E. Jouvin-Marche, and R. Mariuzza. 2004. Standard nomenclature for the superantigens expressed by Staphylococcus. J. Infect. Dis. 189:2334-2336.

Magenis, R. B., E. S. Prudêncio, L. Molognoni, and H. Daguer. 2014. Control method to inspect the compositional authenticity of Minas Frescal cheese by gel electrophoresis. J. Agric. Food Chem. 62:8333-8339.

Maiques, E., C. Ubeda, S. Campoy, S. Salvador, I. Lasa, R. P. Novick, J. Barbe, and J. R. Penades. 2006. B-lactam antibiotics induce the SOS response and horizontal transfer of virulence factors in Staphylococcus aureus. J. Bacteriol. 188:2726-2729.

Martin, M. C., M. A. González-Hevia, and M. C. Mendoza. 2003. Usefulness of a two-step PCR procedure for detection and identification of enterotoxigenic staphylococci of bacterial isolates and food samples. Food Microbiol. 20:605-610.

Mason, W. J., J. S. Blevins, K. Beenken, N. Wibowo, N. Ojha, and M. S. Smeltzer. 2001. Multiplex PCR protocol for the diagnosis of staphylococcal infection. J. Clin. Microbiol. 39:3332-3338.

McLauchlin, J., G. L. Narayanan, V. Mithani, and G. O'Neill. 2000. The detection of enterotoxins and toxic shock syndrome toxin genes in Staphylococcus aureus by polymerase chain reaction. J. Food Prot. 63:479-488.

Mehrotra, M., G. Wang, and W. M. Johnson. 2000. Multiplex PCR for the detection of genes for Staphylococcus aureus enterotoxins, exfoliative toxins, toxic shock syndrome toxin, and methicillin resistance. J. Clin. Microbiol. 38:1032-1035.

Monday, S. R., and G. A. Bohach. 2001. Genes encoding staphylococcal enterotoxins $\mathrm{G}$ and I are linked and separated by DNA related to other staphylococcal enterotoxins. J. Nat. Toxins 10:1-8.

Moraes, P. M., G. N. Viçosa, A. K. Yamazi, M. B. Ortolani, and L. A. Nero. 2009. Foodborne pathogens and microbiological characteristics of raw milk soft cheese produced and on retail sale in Brazil. Foodborne Pathog. Dis. 6:245-249.

Munson, S. H., T. M. Tremaine, J. M. Betley, and A. Welch. 1998. Identification and characterization of staphylococcal enterotoxin types G and I from Staphylococcus aureus. Infect. Immun. 66:33373348.

NCCLS (Clinical and Laboratory Standards Institute). 2003. Methods for dilution antimicrobial susceptibility tests for bacteria that grow aerobically: approved standard. NCCLS document M7-A6. NCCLS, Wayne, Pennsylvania.

Omoe, K., D. L. Hu, H. Takahashi-Omoe, A. Nakane, and K. Shinagawa. 2005. Comprehensive analysis of classical and newly described staphylococcal superantigenic toxin genes in Staphylococcus aureus isolates. FEMS Microbiol. Lett. 246:191-198.

Pereira, V., C. Lopes, A. Castro, J. Silva, P. Gibbs, and P. Teixeira. 2009. Characterization for enterotoxin production, virulence factors, and antibiotic susceptibility of Staphylococcus aureus isolates from various foods in Portugal. Food Microbiol. 26:278-282.

Phillips, I., M. Casewell, T. Cox, B. De Groot, C. Friis, R. Jones, C. Nightingale, R. Preston, and J. Waddell. 2004. Does the use of antibiotics in food animals pose a risk to human health? A critical review of published data. J. Antimicrob. Chemother. 53:28-52.

Rahimi, E., and H. Ghasemian Safai. 2010. Detection of classical enterotoxins of Staphylococcus aureus strains isolated from bovine subclinical mastitis in Isfahan, Iran. Vet. Microbiol. 141:393-394.

Rall, V. L., J. M. Sforcin, M. F. de Deus, D. C. de Sousa, C. H. Camargo, N. C. Godinho, L. A. Galindo, T. C. Soares, and J. P. Araújo Jr. 2010. Polymerase chain reaction detection of enterotoxins genes in coagulase-negative staphylococci isolated from Brazilian Minas cheese. Foodborne Pathog. Dis. 7:1121-1123.

Rea, M. C., S. Goerges, R. Gelsomino, N. M. Brennan, J. Mounier, M. Vancanneyt, S. Scherer, and J. Swings. 2007. Stability of the biodiversity of the surface consortia of Gubbeen, a red-smear cheese. J. Dairy Sci. 90:2200-2210.

Resch, M., V. Nagel, and C. Hertel. 2008. Antibiotic resistance of coagulase negative staphylococci associated with food and used in starter cultures. Int. J. Food Microbiol. 127:99-104.

Rosec, J. P., and O. Gigaud. 2002. Staphylococcal enterotoxin genes of classical and new types detected by PCR in France. Int. J. Food Microbiol. 77:61-70.

Ruaro, A., C. Andrighetto, S. Torriani, and A. Lombardi. 2013. Biodiversity and characterization of indigenous coagulase-negative staphylococci isolated from raw milk and cheese of North Italy. Food Microbiol. 34:106-111.

Sampimon, O. C., T. J. Lam, D. J. Mevius, Y. H. Schukken, and R. N. Zadoks. 2011. Antimicrobial susceptibility of coagulase-negative staphylococci isolated from bovine milk samples. Vet. Microbiol. 150:173-179.

Sergeev, N., D. Volokhov, V. Chizhikov, and A. Rasooly. 2004. Simultaneous analysis of multiple staphylococcal enterotoxin genes by an oligonucleotide microarray assay. J. Clin. Microbiol. 42:2134-2143.

Silva, S. and C. Souza. 2006. Avaliação microbiológica de queijo tipo Minas frescal comercializado na cidade de Belém-Pará. Laboratório Central do Estado do Pará, Centro Tecnológico da Universidade Federal do Pará, Belém, Brazil.

Sneath, P. H. A., and R. R. Sokal. 1973. Unweighted Pair Group Method with Arithmetic Mean. Numerical Taxonomy. Freeman, San Francisco, CA.

Soares, J. C., M. R. Marques, K. Freni, J. O. Tavaria, F. Pereira, M. Xavier, and M. M. Pintado. 2011. Biodiversity and characterization of Staphylococcus species isolated from a small manufacturing dairy plant in Portugal. Int. J. Food Microbiol. 146:123-129.

Stringheta, P. C., T. T. Oliveira, and R. C. Gomes. 2007. Políticas de saúde e alegações de propriedades funcionais e de saúde para alimentos no Brasil. Rev. Bras. Cienc. Farm. 43:2181-2194.

Thomas, D. Y., S. Jarraud, B. Lemercier, G. Cozon, K. Echasserieau, J. Etienne, M.-L. Gougeon, G. Lina, and F. Vandenesch. 2006. Staphylococcal enterotoxin-like toxins U2 and V, two new staphylococcal superantigens arising from recombination within the enterotoxin gene cluster. Infect. Immun. 74:4724-4734.

Ubeda, C., E. Maiques, E. Knecht, I. Lasa, R. P. Novick, and J. R. Penedes. 2005. Induced-induced SOS response promotes horizontal dissemination of pathogenicity island encoded virulence factors in staphylococci. Mol. Microbiol. 56:836-844.

Veras, J. F., L. S. do Carmo, L. C. Tong, J. W. Shupp, C. Cummings, D. A. Dos Santos, M. M. Cerqueira, A. Cantini, J. R. Nicoli, and M. Jett. 2008. A study of the enterotoxigenicity of coagulasenegative and coagulase-positive staphylococcal isolates from food poisoning outbreaks in Minas Gerais, Brasil. Int. J. Infect. Dis. $12: 410-415$.

Viana, F. R., A. L. Oliveira, L. S. Carmo, and C. Rosa. 2009. Occurrence of coagulase-positive staphylococci, microbial indicators and physica-chemical characteristics of traditional semi hard cheese produced in Brazil. Int. J. Dairy Technol. 62:372-377.

Virdis, S., C. Scarano, F. Cossu, V. Spanu, C. Spanu, and E. P. L. Santis. 2010. Antibiotic resistance in Staphylococcus aureus and coagulase negative staphylococci isolated from goats with subclinical mastitis. Vet. Med. Int. 2010:517060.

Zell, C., M. Resch, R. Rosenstein, T. Albrecht, C. Hertel, and F. Götz. 2008. Characterization of toxin production of coagulase-negative staphylococci isolated from food and starter cultures. Int. J. Food Microbiol. 127:246-251. 